\title{
Syntactic study of mining and metallurgical terms with a negative affix
}

\author{
Qayumova Munavvar Sanakulovna \\ Navai State Pedagogical Institute, PhD. Uzbekistan \\ Khayriddinova Zarnigor Vahobiddinovna \\ Navai State Pedagogical Institute, first year student of \\ "English and literature" direction. Uzbekistan
}

\begin{abstract}
The following article is devoted to identifying the main problems of translation of metallurgical texts, the peculiarities of translation of terms and terminological combinations in the metallurgical sphere.

Key words: term, scientific and technical translation, metallurgy, lexical equivalents, terminological combinations.

Due to the lack of the usual correspondences of metallurgical terms, difficulties arise in translation. In this situation, we need to analyze the problems that have arisen and find ways to solve them.
\end{abstract}

Terminology is (terminology and logic) - 1) an area of vocabulary; specific science, techniques, production. A set of terms related to the relevant system of concepts in the industry, arts, and social activities; 2) Linguistic terms study of terms. Terminology is a specialized vocabulary in a narrow area. Terminological vocabulary develops with it as an integral part of the national language vocabulary, and undergoes all processes of development of society and language. A specific terminology is formed in that language only when a particular field or science is highly developed. The development of terminology, the ways of enrichment: different vocabulary, new vocabulary, lexicalization of certain verbal categories, semantic overlap of vocabulary, etc. Today richness of Uzbek terminology is mainly due to the use of other languages and word formation is giving. The main factor that determines the stability of a particular terminological system in a particular field is its regularity. Terminology has its own peculiarities. For example, if the common language is synonymy, harmony, and richness of the language, it is a negative phenomenon in terminology. The Uzbek language has gone through a well-known path of development. Work in the terminology of the Uzbek language was carried out in the 50s of thelast century by the Language and Literature Committee at the Presidium of the Supreme Soviet of the Uzbek SSR (since 1931-37), then by the terminology department at the Institute of Language and Literature of the Academy of Sciences of Uzbekistan.

Today, the use of the Chinese language in metallurgy has increased. Translation of metallurgical texts is considered one of the most difficult types of scientific and technical translations. Its complexity lies in the fact that without sufficient knowledge of the language of engineering and technical realities, it is impossible to perform an accurate and correct translation.

Metallurgical text is a scientific and technical document covering the processes of obtaining metals from ores or other materials, as well as processes associated with changes in the chemical composition, structure and properties of metal alloys. First, it should be borne in mind that texts with a metallurgical specificity, like any text of a scientific and technical genre, are usually full of terms and terminological combinations.

The term "terminology" in modern linguistics is used in different meanings. In accordance with the structure of this term (it is a combination of the word "term" and Greek. Logos - "word, doctrine") 
it denotes the doctrine of the terms, the section of linguistics (lexicology), engaged in the study of terms, or the corresponding scientific (applied) discipline. However, in this sense, the named term is used extremely rarely. Recently, to denote this concept, some linguists use the term "terminology", which is similar in structure. A terminology in linguistics is most often called a set of terms used in a particular language or in a particular field of activity of people. In the last value, i.e. To denote the concepts of a certain field of knowledge or any field of activity, the composite term "terminological system" or the complex formation "terminological system" created on its basis is often used. In understanding the term as a unit of terminology, or an element of a terminological system, the opinions of linguists differ significantly, which is reflected in the definition (explanation) of this concept by different scientists. It is obvious that the term, like any other symbolic unit of the language, has an exponent, or signifier, and content, or signified, but researchers have different ideas about the exponent and the content of the terminological sign. The exponent (signifier) of a terminological unit is traditionally considered a word, although most modern linguists as an exponent of a term consider not only a single word, but also a combination of different words, more precisely, a phrase. When defining the concept of a term as the closest generic concept, some scientists call the word, respectively (for example, the works of R. A. Budagov, A. A. Reformatsky, M. I. Fomina, H. M. Shansky). Others - word or combination of words, phrase, expression, compound name, etc. (the works of O. S. Akhmanova, B. N. Golovin, A. V. Kalinin, V. I. Kodukhov, R. Yu. Kobrin, and others). At present, it seems, no one doubts that the term can be not only a single word. Although there is no complete clarity on the question of which phrases can be terms and which ones are not. There is no consensus on the question of the morphological properties of the term, its part-related affiliation. Some linguists recognize in terms only nouns and substantive phrases, i.e. phrases with a reference word - a noun, others do not consider this feature mandatory for the term, i.e. recognize significant words in terms of different parts of speech and phrases built on their basis, called compound terms. In modern linguistics, the first point of view prevails, which seems more convincing. According to A. I. Moiseyev, for example, "the linguistic form of expression of terms are nouns and phrases based on them." According to him, "terms are words and phrases of a strictly nominative function, namely, a certain type of nouns and phrases based on them," "this is a strictly nominative part of special and general vocabulary and phraseologyin the form of nouns and phrases based on them". The validity of this view of the term is confirmed, in particular, by the fact that "only certain categories of nouns and stable combinations based on them have a nominative function in the strict sense." As for the words of other parts of speech, they are indirectly related to terminology. According to B. N. Golovin, the terms are limited to "the properties of the parts of speech: the adjective, verb, adverbs are not included in terminological relations independently, but through the medium of a noun". ${ }^{1}$

The terms represent the official names of the special concepts. In addition to each term, the definition is obligatory for the understanding of the term. Accordingly, it is intended to be understood in accordance with the following terms and conditions, and especially in normal and formal business. According to the majority of specialists in terminology and linguistics, the following basic requirements are presented to the terms: Uniqueness within the limits of this terminological system; lack of synonyms; neutrality with an emotional expressive point of view; clearly defined content;

\footnotetext{
${ }^{1}$ Norova M.B. Narziyeva I.Z. Terms and terminology in the Uzbek and English languages. International Journal on integrated education. e-ISSN:20203502 p-ISSN:26153785 Impact factor. -173-176p.
} 
short. However, these requirements are not always observed in order to keep the communication in the area of sales, technology, and control. Even in linguistics, terms are synonymous; meaningful terms. The use of such terms in speech requires special attention. Many terms are required to be used in such a way that they allow to reveal their exact value, which in turn leads to excessive. The synonymous terms take up the perception of the text, cause the adherence to the statement about the fact that this term is not new Therefore, it is necessary to run to the parallel use of terms - synonyms: paleotalized (soft) consonant, explosive (otherwise - explosive, or instantaneous) consonant, etc. Highly specific terms, used outside this terminology, outside the scope of the night, techniques or art, require an understanding. Here, for example, the well-known hippirig and the H. M. Amosov dye will include the terms in the "Thoughts and Selections": We need fibrillation - a non-optimal superficial tremor of the cord muscle, replacing the normal, slight, central contraction; The protrusion of the wall of the aorta was formed - an aneurysm. If the terms are incomprehensible, they do not fulfill the information function and interfere with the speech. It deprives accessibility, takes its perception, as well as the malicious use of the terms, especially in speech, intended for a tobacco unit. It should be noted that the use of terms beyond the usual style is connected with their determinism, a change of meaning, and the use of them. Such use of the terms is available in the publicity, user-friendly literature, open speech: The reader is our kind, so that it is a matter of personal concern.

A term is a lexeme, phraseme or derivational morpheme that has at least one meaning known to a narrow circle of native speakers - specialists in a particular field. Each lexical unit of a language can become a term if it moves into a certain highly specialized area and will denote certain concepts in this area. Terminological phrases are semantically integral phrases of two or more words that are related by a preposition or in a non-sentence way. They will be either stable expressions or free verbal phrases.

There are two main problems in the translation of terminology:

1. The use of highly specialized vocabulary as an element of the distribution of content in texts for translation;

2. The problem of translation of terms and attempts to find matches in foreign languages.

The first problem is important because in scientific and technical texts or production documents, terminology is the main burden. They are very informative and are often keywords. The second problem is because even in related languages, there are inconsistencies and there is a danger of changing the meaning of the text when using the wrong version of the terminological translation.

When considering a terminological translation from a lexical point of view, two situations can arise - the first is associated with the equivalents of the term in the original in written translation, which can be in dictionaries, and the second is the situation when there are no equivalents of the original term.

In the first situation, one or more equivalents can be encountered, but such a situation should not cause particular problems if there is only one equivalent. In this case, it is only necessary to check whether the replacement will be adequate in this context. If there are several equivalents, it is necessary to choose the most appropriate one for your text, but this is not always easy to implement due to the frequent mismatch of terms. The main difficulty for a translator when translating texts with abundant use of the metallurgical terminology of the Chinese language is the impossibility of searching for terms of this specificity due to the absence of dictionaries of metallurgical terminology. This problem negatively affects the translation of metallurgical texts. A large number of meanings of terms is one of the features in the translation of metallurgical texts. This is due to unsettled terms, which, ideally, should simplify translation, since the translator focuses on them, but due to the ambiguity, the terms are not satisfactory within this specialty.

As an example, consider the term "condition", which has such meanings as: processing procedure, 
and technological process. The meaning of this term in context will always depend on the words next to that term. In this situation, the translator should use a terminological dictionary in which he could find the meaning of the term. However, due to the lack of such dictionaries, the translator is forced to look for other ways to find the meaning of this term in the context. We can say that the translation of metallurgical specific texts is greatly influenced by the way the translator owns the terms in metallurgy. Often, the same terminological phrases can mean different things that are indicated in dictionaries and cannot be used in translation in the text of highly specialized terminology. As an example, consider the terminological combination "Overburden layers", which has the following dictionary meanings: overburden overload, overcharge, and none of these meanings can be used in the context of nanotechnology related to metallurgy, since its contextual meaning will be "protective layer".

In the Chinese language, when translating terms and terminological phrases, especially those that are not related to the non-existence of narrow-profile metallurgical dictionaries. The first thing to do is to indicate the absence of a formal numerical attribute in the Chinese language, because of this, difficulties arise in finding the singular or plural, there are great difficulties during the translation of metallurgical texts, in which accuracy is an important component. For example, "Improving the quality effects of seedlings and shavings and silicon casing layer", "improving the impact of the thermal stability of nickel silicide through ion implantation and a zinc protective layer".

The terminological phrase "Overburden layer" does not allow the translator to find out how many protective layers are meant. In such situations, the translator is sometimes helped by the context, but it really helps to become familiar with the device, which is described in the context or certain equipment. One of the characteristic grammatical features of the Chinese language is that the subject can be not only one word, but also a phrase, and in some cases even a whole sentence. This is a difficulty for the translator, since it is difficult to determine the subject itself among the other members of the sentence. For example, "further, in the silicide with the phosphorus implant, the creation of a high numerical value of the resistance is found". In this example, the subject is the phrase "Silicides according to P bukuo", and this changes our tactics when translating terminological phrases. Besides the heavy congestion of the available definitions of the word, which is usually often found in scientific and technical texts in the Chinese language, one may encounter the difficulty of finding a connection between parts of complex definitions. For example, re-measurement of silicon resistance - "the numerical value of the resistance of nickel silicide". In addition to all of the above, it is worth keeping in mind that in every text of the scientific and technical style, and especially in metallurgical ones, we come across jargon (professional) that cannot be found in dictionaries. From this, we have that, when translating metallurgical terminology, it is important to remember to pay attention to the context that limits the terminology. And even if the translator was able to find a suitable terminological meaning, due to the lack of narrow-profile metallurgical dictionaries, the found meaning may not have the necessary contextual meaning and mistakes will be made in the future because of this. In addition to clear advice to study scientific and technical texts that are directly related to the specifics of translation, you should know which direction in metallurgy is indicated in the text. This will help you find the meaning used in context using dictionaries. The number of terms are used in the field of metallurgy ranges from 200,000 to 500,000 .

V.N. Komissarov and Ya. I. Retsker studied the specifics of terms and possible ways of their translation in their works [1]. In the terminology of the affected area, there are a large number of abbreviations, abbreviations, substitution of phrases with complex words and nomenclature designations. Metallurgical terms also include metal science and metal technology, flaw detection and quality control, metallography, ore preparation, production of cast iron and ferroalloys, recycling of metal recyclables, welding, rolling and drawing production, metal processing, terms and phrases and these areas.

The question of the origin of the language, the first language, has been of interest to mankind since 
ancient times. Since ancient times, there have been many theories and teachings about the origin of language. However, these theories and doctrines have not yet completely resolved the question of the origin of language.

\section{References:}

1. Mirziyoyev Sh. Oliy ta'limda foydalaniladigan nashrlar va axborotlarni uzatishning zamonaviy manbalari. 19 май 2018 й.

2. BakhtinM.M. Aesthetics of verbal creativity. - M., 1986. - Pp. 22-43.

3. BuberM. You and Me; Dialogue // M. Buber. Two images of faith. M., 1995, M.M. Bakhtin Theaesthetics of verbal creativity. Moscow: Iskusstvo, 1986.

4. HerderI.G. Idea to the philosophy of history. - M., 1977. - P. 224.

5. Herder I.G. Idea to the philosophy of history. - M., 1977. - P. 230.

6. DanilevskyN.Y. Russia and Europe. - Moscow, 1991. - P. 109.

7. Emelyanov Yu.N. Introduction to Cultural Anthropology: a manual. St. Petersburg, 1992. - P.14.

8. KondakovI.V. Cultural Studies: History of Russian Culture: Lectures. - Moscow: IKF OmegaL.Vysshaya Shkola, 2003. - Pp. 416, 423.

9. Norova M.B. Narziyeva I.Z. Terms and terminology in the Uzbek and English languages. International Journal on integrated education. e-ISSN:20203502 p-ISSN:26153785 Impact factor. $-173-176 \mathrm{p}$.

10. .Semenov V.A. Pedagogical situations: a manual. - M., 2001. - P. 21.

11. 10.Sorokin P. Social and cultural dynamics // Sorokin P. Man. Civilization. Society. - Moscow, 1992

12. Tetdoeva S.A. Historical memory as a sociocultural phenomenon. - St. Petersburg, 1998. - P. Philosophical Dictionary / Ed. M.M. Rozental. - Third Ed. - M., 1975. - P. 59.

13. Akramova Gulbahor Renatovna, Akramova Surayo Renatovna. Pedagogical and psychological conditions of preparing students for social relations on the basis of the development of critical thinking. Psychology and education. Vol. 58 No. 2 (2021): Volume 58 No. 2 (2021). P. 48894902 http://psychologyandeducation.net/pae/index.php/pae/article/view/2886

14. Aminova Feruza Hayitovna. Axiological analysis of socio-aesthetic problems in hadiths An International Multidisciplinary Research Journal 1457-1462, 2020. https://www.indianjournals.com/ijor.aspx $?$ target $=$ ijor:aca $\&$ volume $=10 \&$ issue $=5 \&$ article $=212$

15. Aminova Feruza Hayitovna. Основные принципы исследовательского обучения в школе 2018 international scientific review of the problems of pedagogy and psychology 19 aprel $2018 \mathrm{https}: / /$ scientific-conference.com/images/PDF/2018/1/basic-principles.pdf

16. Amonov Ulugmurod Sultonovich. Abdurauf Fitrat is one of the earliest researchers of uzbek folklore. "Academicia” An International Multidisciplinary Research Journal, India. June 2020. 669-673 p. 10.5958/2249-7137.2020.00616.3

17. https://www.indianjournals.com/ijor.aspx?target=ijor:aca\&volume $=10 \&$ issue $=6 \&$ article $=096$

18. Amonov Ulugmurod Sultonovich. Folklore in the works of Abdurauf Fitrat. International scientific journal «Theoretical \& Applied Science», USA. September 30, 2016. 12-15 p. 
https://www.semanticscholar.org/paper/folklore-in-the-works-of-abdurauf-fitrat amonov/dcc79abce08ba4602c2dc5b5ae3a87b345797d63

19. BuryakovYu.F. The history of non-ferrous metals in Uzbekistan in antiquity and in the Middle Ages. // Materials of the Republican Scientific and Practical Conference. NEVELLAND. - C11.

20. CM: Kuchersky N.I, Astanzaturian G.G. BerdnikovE.A.Navoi. CGA RUZ. F - M 20, OP. 16, units. XP.62, 1. 19. Norma.uz National Database of Legislation, 06.03.2020, No. 07/20/4629/0258)

21. Eshonkulova Dilafruz Husenkizi . Ways to develop critical thinking in adolescents An International Multidisciplinary Research Journal184-188 2020, https://www.indianjournals.com/ijor.aspx?target=ijor:aca\&volume $=10 \&$ issue $=10 \&$ article $=024$

22. Жумаева Ф Р. Использование разных видов текстов в качестве дидактического материала на уроках русского языка. https://cyberleninka.ru/article/n/ispolzovanie-raznyh-vidov-tekstovv-kachestve-didakticheskogo-materiala-na-urokah-russkogo-yazyka

23. Жумаева Ф. Р., Хакимова Н. Х. Формирование языковой и коммуникативной компетенции учащихся при работе над текстом. http://eclss.org/publicationsfordoi/istanbulonline.pdf\#page $=168$

24. Ruziyevna J. F, Baxronovna M. F. Tolerance is the basis for creating a humanistic culture in the world. Academicia: An International Multidisciplinary, 2020. https://www.indianjournals.com/ijor.aspx ?target=ijor:aca\&volume=10\&issue=5\&article=254

25. Khodjieva Farogat Oltievna The Actuality And The Content of Forming Critical Thinking Skills Of Primary School Pupils Psychology and Education Journal 2020. http://psychologyandeducation.net/pae/index.php/pae/article/view/986

26. Muradova Dilfuza Zhurakulovna. 58-60 2020 The formation of communicative competence of pupils primary school. European Science58-60 2020 https://scientificpublication.com/images/pdf/2020/52/european-science-3-52-.pdf

27. Rasulov Jasur Saparovich Effects of training based on neuropedagogy International Scientific Review of the Problems and Prospects of Modern Science and Education 30.08.2018 https://scientific-conference.com/h/sborniki/pedagogicheskie-nauki2/1376-effektyobucheniya.html

28. RizaevS.NavoiyGorno-Metallurgical. - Tashkent: Shark, 2008.- C. 86.

29. Ryziqulova Amina Totliboyevna. The role of national values in ensuring the stability of marriage and family relations in modern uzbek families. ACADEMICIA: An International Multidisciplinary Research Journal 88-93 $2020 \quad$ 10.5958/2249-7137.2020.01126.X. https://saarj.com/wp-content/uploads/ACADEMICIA-OCTOBER-2020-FULL-JOURNAL.pdf.

30. Sattorovna Jamilova Bashorat, Sadriddinovna Nuriddinova Shaxnoza The spiritual description of adults in uzbek children's prose-the place of literary psychologism. Academicia: an international multidisciplinary research journal. Year: 2021, Volume:11, Issue:1

31. See: Batalova I. Gaev Y. Combine, time, fate. Tashkent. Abu Ali Ibn Sina Medical Literature Sina Ali. - C. 57.

32. Shalatonin B.S. "Shadows on the rocks" - T: A. Kadyri, 1999. - C.20.

33. Shamsutdinov R., Мўминов Н.ўзбекистонTarios. -T.: Sharc; 2013. -b. 25. 
34. Temirov, Odinaeva Z. CadimgiDipboard Con-metallurgy Tarios. - T.: Yanga ASR Avlodi, 2008. - B.8.

35. Temirov, Odinaeva Z. CadimgiDipboardKon-Metallurgy Tarios. - T.: Yangang ASR Avlodi, 2008. -B. 15

36. Tukmuradova Malika Elmurodovna. Impact of digital education on delivering English lessons An International Multidisciplinary Research Journal1787-1791,2020 https://www.indianjournals.com/ijor.aspx?target=ijor:aca\&volume=10\&issue=11\&article=289

37. Usmanov K. The history of Uzbekistan. - T: "Shark", 2007. - p.64.

38. Xalilova Ruxsora Raupovna. The Formation Of Professional Speech Of Students In The Learning Process At The University. European Journal of Research and Reflection in Educational Sciences Vol 7. 2019 http://www.idpublications.org/wpcontent/uploads/2019/09/Full-Paper-THE-FORMATION-OF-PROFESSIONAL-SPEECH-OFSTUDENTS-IN-THE-LEARNING-PROCESS-AT-THE-UNIVERSITY.pdf

39. Абилова Гаухар Оринбековна. On the issue of training highly qualified teachers. International Scientific Review of the Problems and Prospects of Modern Science and Education. 2018 https://scientific-conference.com/h/sborniki/pedagogicheskie-nauki2/952-on-the-issue.html

40. Ахатова Дурдона Актамовна. Didactic Opportunities to Ensure Compliance With The Goal And Content Of Education in The Modernization Process International Scientific Review of the Problems and Prospects of Modern Science and Education12 dekabr 2019 yil https://scientific-conference.com/h/sborniki/pedagogicheskie-nauki2/2071-didakticheskievozmozhnosti.html

41. Ахатова X. А. 2019. Факторы повышения эффективности воспитания гармоничного поколения в образовании International Scientific Review of the Problems and Prospects of Modern Science and Education 12 dekabr 2019 yil. https://scientificconference.com/h/sborniki/pedagogicheskie-nauki2/2070-faktory-povysheniyaeffektivnosti.html

42. Баходир Маъмуров. Акмеологик Ёндашув Асосида Бўлажак Ўқитувчиларда Таълим Жараёнини Лойихалаш Кўникмаларини Ривожлантириш. Том 1 № 1 (2020): Таълим ва инновацион тадқиқотлар. http://interscience.uz/index.php/home/article/view/15

43. Башорат Жамилова, Мохигул Каххорова. Болалар детектив насридаўсмирлар рухияти тасвири. Том 1 № 1 (2020): Таълим ва инновацион тадқиқотлар. http://interscience.uz/index.php/home/article/view/37

44. Лукмонова С.Г. Цифровые образовательные ресурсы в педагогической деятельности [Digital educational resources in teaching] // XXI International scientific review of the problems of philosophy, psychology and pedagogy. https://scientificconference.com/h/sborniki/yuridicheskie-nauki2/2249-media-security-trend.html

45. Махмудов Мэлс. Дидактик Лойихалаш - Замонавий Таълимда Самарадорлик Кафолати. $\begin{array}{llllll}\text { Том } & 1 & \text { № } & 1 & \text { (2020): }\end{array}$ http://interscience.uz/index.php/home/article/view/14

46. Рўзиева М. Ё. Туркий халқлар фольклорида ранг ифодаловчи сўзлар ва уларнинг семиотик тахлили. Том 1 № 1 (2020): Таълим ва инновацион тадқиқотлар. http://interscience.uz/index.php/home/article/view/34 
47. Эльчиева Динара Толубаевна . Формирование познавательного интереса и познавательной активности младших школьников European Science50, 2020 June. https://scientific-publication.com/images/PDF/2020/53/EUROPEAN-SCIENCE-4-53-.pdf 